\title{
PHYSICAL PROPERTIES OF BRAZIL NUTS
}

\section{ROBERTA M. NOGUEIRA ${ }^{1}$, VIRGÍNIA DE S. ÁLVARES ${ }^{2}$, SOLENIR RUFFATO ${ }^{3}$, ROBERTO P. LOPES ${ }^{4}$, JUAREZ DE S. E SILVA ${ }^{5}$}

\begin{abstract}
The Brazil-nut, also known as Para-nut, is widely used as food and in cosmetic industries. The seeds are rich in lipids and protein, and also present a considerable amount of selenium. Limited research has been conducted on postharvest of the Brazil nut, being an important information to design equipment related to aeration, drying, storage and transportation steps. Thus, the objective of this study was to determine the physical properties of the Brazil-nut with and without tegument. The dimensions found for the almonds with tegument were $39.35 \mathrm{~mm}$ in the $\mathrm{X}$ axis, $24.19 \mathrm{~mm}$ in the $\mathrm{Y}$ axis, and $17.88 \mathrm{~mm}$ in the $\mathrm{Z}$ axis. However for the almond without tegument the values were $31.05 \mathrm{~mm}$ in $\mathrm{X}, 14.38$ in $\mathrm{Y}$ and $15.91 \mathrm{~mm}$ in $\mathrm{Z}$ axis. The sphericity was $66.40 \%$ and $51.59 \%$ for the kernels with and without seed tegument respectively. The kernels with and without tegument presented sphericity of $63.00 \%$ and $47.72 \%$ respectively. The mass of 1000 almonds was $6.13 \mathrm{~kg}$ for almond with teguments and $3.18 \mathrm{~kg}$ for almonds without teguments. Specific mass of $0.947 \mathrm{~g} . \mathrm{cm}^{-3}$ and $1.003 \mathrm{~g} . \mathrm{cm}^{-3}$ for the kernels with and without tegument, coupled with a porosity of $46.88 \%$ and $37.60 \%$ and, resulting on a bulk density of $0.504 \mathrm{g.cm}^{-3}$ and 0.626 g. $\mathrm{cm}^{-3}$ for almonds with and without teguments respectively. Finally, the angle of repose for the kernels with teguments was $36.37^{\circ}$.
\end{abstract}

KEYWORDS: Brazil nut, physical properties, postharvest.

\section{PROPRIEDADES FÍSICAS DA AMÊNDOA DA CASTANHA-DO-BRASIL}

RESUMO: A castanha-do-brasil, também conhecida como castanha-do-pará, é muito utilizada na alimentação humana e na indústria cosmética. As sementes são ricas em lipídeos e proteínas, apresentando ainda uma quantidade considerável de Selênio. Poucas pesquisas vêm sendo realizadas na pós-colheita do produto, sendo as propriedades físicas importantes para o desenvolvimento de equipamentos relacionados à aeração, secagem, armazenamento e transporte de produtos. Assim, neste trabalho, teve-se por objetivos: determinar as propriedades físicas da castanha-do-brasil com e sem tegumento. O tamanho para as amêndoas com tegumento, foi de $39,35 \mathrm{~mm}$ no eixo $\mathrm{X}, 24,19 \mathrm{~mm}$ no eixo $\mathrm{Y}$ e $17,88 \mathrm{~mm}$ no eixo $\mathrm{Z}$; já para a amêndoa sem tegumento os valores foram de 31,05 $\mathrm{mm}$ em X, 14,38 $\mathrm{mm}$ em Y e 15,91 em Z. A esfericidade foi de $66,40 \%$ e $51,59 \%$, para as amêndoas com e sem tegumento, respectivamente. $63,00 \%$ e 47,72\% foram os valores de esfericidade encontrados para as amêndoas com e sem tegumento, respectivamente. A massa de 1.000 amêndoas foi de $6,13 \mathrm{~kg}$ para a amêndoa com tegumento e de $3,18 \mathrm{~kg}$ para amêndoas sem tegumento. Valores de massa específica de 0,947 g.cm $\mathrm{cm}^{-3}$ e de 1,003 g. $\mathrm{cm}^{-3}$ para as amêndoas com e sem tegumento, associados a uma porosidade de 46,88\% e 37,60\%, produziram uma massa específica aparente de $0,504 \mathrm{~g} \cdot \mathrm{cm}^{-3}$ e de $0,626 \mathrm{~g} . \mathrm{cm}^{-3}$. Finalmente, o ângulo de repouso para as amêndoas com tegumento foi de $36,37^{\circ}$.

PALAVRAS-CHAVE: Castanha-do-brasil. propriedades físicas. pós-colheita.

\footnotetext{
${ }^{1}$ Eng $^{\mathrm{o}}$ Agrícola, Prof. Dr., Instituto de Ciências Agrárias e Ambientais, UFMT/Sinop - MT, Fone: (66) 3531-3161, roberta_nogueira@ufmt.br.

${ }^{2}$ Eng $^{\mathrm{o}}$ Agrônomo, Pesquisador A, CPAFAC, EMBRAPA/Rio Branco - AC, virginia.alvares@embrapa.br.

${ }^{3}$ Eng $^{\circ}$ Agrícola, Prof. Doutor, Instituto de Ciências Agrárias e Ambientais, UFMT/Sinop - MT, soleruffato@gmail.com.

${ }^{4}$ Eng $^{\circ}$ Agrícola, Prof. Doutor, Departamento de Engenharia Agrícola, UFV/Viçosa - MG, roberto.precci@ufv.br.

${ }^{5}$ Eng ${ }^{\mathrm{o}}$ Agrícola, Prof. Doutor, Departamento de Engenharia Agrícola, UFV/Viçosa-MG, juarez@ufv.br.

Recebido pelo Conselho Editorial em: 9-4-2012

Aprovado pelo Conselho Editorial em: 30-3-2014
}

Eng. Agríc., Jaboticabal, v.34, n.5, p. 963-971, set./out. 2014 


\section{INTRODUCTION}

Bertholletia excelsa Bonpl. (Lecythidaceae), the species that produces the Brazil nut, can be found in Bolivia, Ecuador, Peru, Guyanas and Brazil, countries which include the Amazon rainforest region. In Brazil, their occurrence is reported in the states of Acre, Amapá, Amazonas, Para, Rondonia, Roraima and northern of the states of Mato Grosso and Goiás (LOUREIRO \& SILVA 1968; LOUREIRO et al 1979; SOUZA et al 2004.).

The nuts fruit is known as hedgehog containing 12 to 25 seeds. The seeds, known as Brazil nut have angled triangular shape and are composed of two layers of seed tegument: the forehead and the tegmen. Internally, it has an atypical embryo, triangular and shows no distinction of cotyledons, hypocotyl-radicle axis and plumule (SANTOS et al., 2006).

During collection, the nuts are removed from the fruit; however, remain with the seed tegument to ensure the lowest level of degradation. The removal of the seed tegument only occurs during industrial processing.

The Brazil nut has its diverse use, highlighting their nutritional importance, due to its high content of proteins, lipids, fiber, vitamins and minerals, with special emphasis on selenium concentration (CARDARELLI \& OLIVEIRA 2000); in addition to extensive use in the cosmetic industry, which allows the generation of income for approximately 15,000 families living on the extraction of the product, ensuring the conservation of the species (SANTOS \& SOUZA, 2012). As additional form, processing and marketing of primary production directly by extractivists is an important step in the production chain (MACIEL \& REYDON, 2008).

As food, the Brazil nut has many important characteristics for its processing. Among these characteristics, the physical properties are the most important steps for post harvest; as well as nutritional parameters provides indispensable information to its industrialization.

Few studies have been performed in Brazil nut post harvest, mainly in developing technologies for processing and storage of chestnuts on the prior step to the industry. Currently, the drying is done under unsuitable conditions to the product by exposing the product to unpaved yards under very unfavorable local climatic conditions such as high rainfall, characteristic of the producing regions.

However, the development of the drying and storage systems of agricultural products initially passes through knowledge of the physical and chemical characteristics of the product being processed (SILVA, 2008). Regarding the chestnut seeds, the physical properties of the product with the seed tegument are fundamental to the development of technologies related to drying and storage at the producer level, before being forwarded to industry. The knowledge of the physical properties of the product without tegument implies to the essential development parameters of new technologies and equipment for the industrial processing

RAZAVI et.al. (2008) also emphasizes the importance of determining the physical properties of the grains and seeds for the design of equipments for the processing, transportation, selection, separation and storage. The authors mention that the design of these equipments without prior knowledge of the physical properties will result in unsatisfactory results. Exemplifying the applications, it is described that the size and shape are important for the classification and separation of the product; the actual and apparent specific mass are necessary for the design of processing and storage equipments such as silos and dryers; the porosity of almonds is the most important factor for packing; since the angle of repose is critical in determining the storage and packaging structures. SILVA (2008) mentions that the knowledge of these parameters can be critical for the adaptation of systems aimed the improving of its performance and efficiency.

This study aimed to determining the physical properties of the Brazil nut seeds, with and without seed tegument, crop moisture, comparing data with data from the literature as well as linking up such properties between the product with and without seed tegument. 


\section{MATERIALS AND METHODS}

Seeds of the Brazil nut (Bertholletia excelsa HUMB \& BONPL.) used for the test, derived from the municipality of Itaúba-MT, harvested during the period 2010/2011. The crop harvesting method used for the tests was to gather fruit on soil, typical method for the product; the seeds were manually extracted and a previous selection was performed, separating only apparently healthy seeds. Parts of the seeds were peeled manually using only the whole seeds obtained through this process.

\section{Seed size and shape}

The seeds of the chestnuts differ as to its geometric shape, or even with the seed tegument; it has a pyramidal shape and when are benefited (without seed tegument) appears as ellipsoids.

The form factor was determined by the sphericity and roundness of 100 seeds with and without seed tegument, according to equations 01 and 02, cited by CORREAA \& SILVA (2008).

For the determination of the parameters used in equations 01 and 02 (diameter and area) a high resolution scanner was used and images were treated in the open software GNU Image Manipulation Program (GIMP). The methodology was used to determine the number of pixels contained in the image of interest (chestnut) and comparing this value with the total number of image pixels. Based on the total area of the image, it was possible to determine the selected image area.

$$
E=\frac{d_{i}}{d_{c}}
$$

wherein,

$$
\begin{aligned}
\mathrm{E} & =\text { Sphericity }(\mathrm{adm}) \\
\mathrm{d}_{\mathrm{i}} & =\text { Diameter of the inscribed circle }(\mathrm{mm}), \text { and } \\
\mathrm{d}_{\mathrm{c}} & =\text { Diameter of the circumscribed circle }(\mathrm{mm}) . \\
C & =\frac{A_{p}}{A_{c}}
\end{aligned}
$$

wherein,

$$
\mathrm{C}=\text { Circularity }(\mathrm{adm}) \text {; }
$$

$\mathrm{A}_{\mathrm{p}}=$ Projected area of the seed $\left(\mathrm{mm}^{2}\right)$, and

$\mathrm{A}_{\mathrm{c}}=$ Area of the circumscribed circle $\left(\mathrm{mm}^{2}\right)$.

The size of the seeds was determined by evaluating the dimensions along the three axes that make up its form, with the aid of a digital caliper with a resolution of $0.01 \mathrm{~mm}$. In Figure 01 (a / b), can be seen the pyramidal and spheroid forms of the Brazil nut, with and without seed tegument, respectively. Fifty seeds were used in both cases.

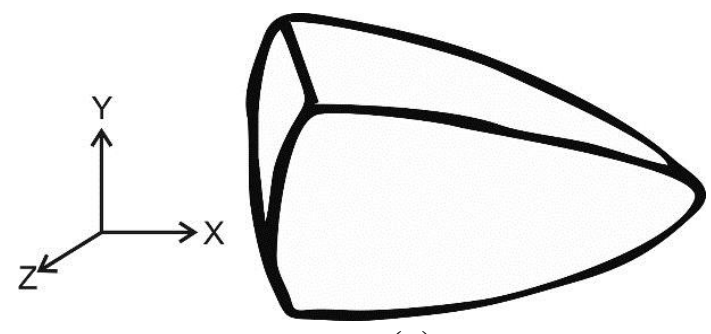

(a)

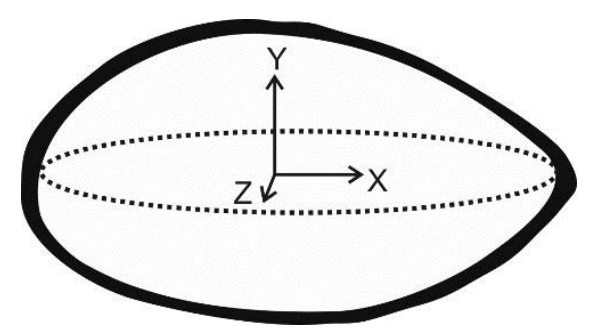

(b)

FIGURE 1. Shape of Brazil nut (a) with seed tegument and (b) without seed tegument. 


\section{Mass of 1000 seeds}

The mass of a lot of 1000 almonds (with and without seed tegument) was determined by semi-analytical electronic balance with a resolution of $0.01 \mathrm{~g}$ and the result is expressed in $\mathrm{kg}$. by 10 .

For this analysis, 100 randomly selected almonds were used and the obtained mass multiplied

\section{Actual specific mass}

The specific mass was determined by adapting the methodology mentioned by Mohsenin (1986) using the Archimedes principle for determining the unitary volume. Each sample of chestnut, with and without seed tegument, was fixed on a stand and completely immersed in a Becker containing metallic mercury, which was placed on a balance (Figure 2). The unitary mass was determined using a balance accurate to $0.01 \mathrm{~g}$.

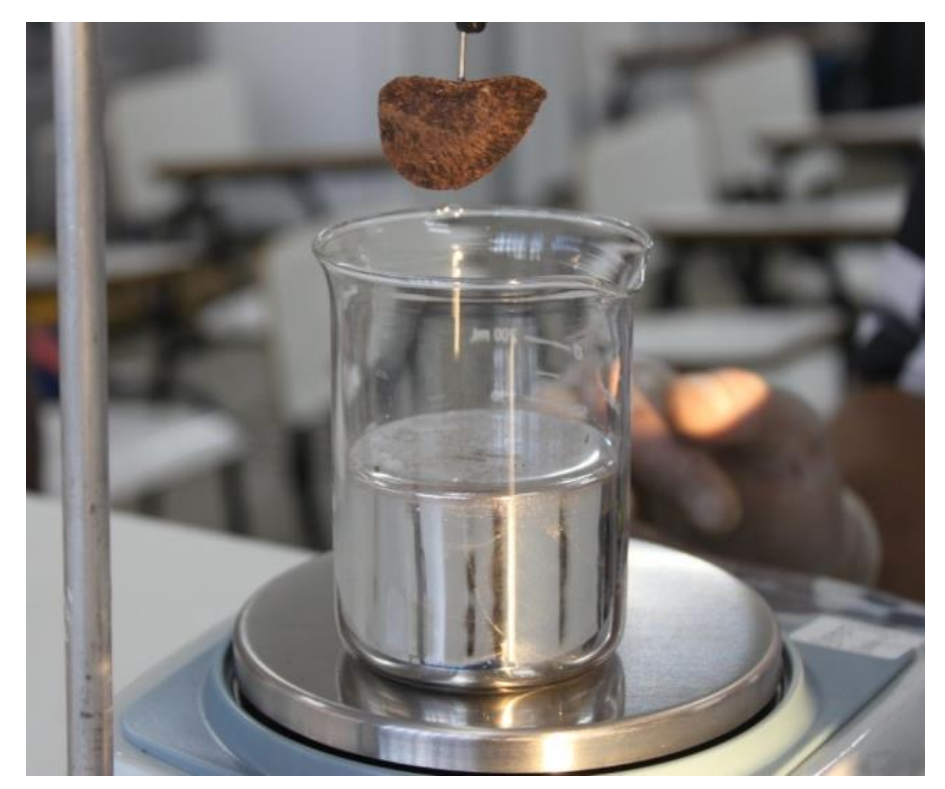

FIGURE 2. Determination of Unitary Specific Mass in the Brazil nut.

From the unit sample mass data and the mass variation in the fluid (unitary volume), the chestnut specific mass was determined using equation 3.

$$
\rho_{\text {actual }}=\frac{m_{\text {sample }} \cdot S G}{m_{H g}}
$$

where,

$$
\begin{aligned}
& \rho_{\text {actual }}=\text { specific mass of the chestnuts }\left(\mathrm{kg} / \mathrm{m}^{3}\right) \\
& \mathrm{m}_{\text {sample }}=\text { mass of the sample }(\mathrm{kg}) ; \\
& \mathrm{SG}=\text { relative density of mercury }(\mathrm{adm}), \text { and } \\
& \mathrm{m}_{\mathrm{Hg}}=\text { mercury mass change after immersing the sample }(\mathrm{kg}) .
\end{aligned}
$$

\section{Porosity}

The porosity of the nuts, with or without seed tegument was determined by the volume of liquid complementation method using soybean oil as the reference liquid. The pattern established volume was $250 \mathrm{ml}$, using a beaker as container. To read the liquid volume of complementation it was used a measuring cylinder with a volume of $250 \mathrm{ml}$ and $2 \mathrm{ml}$ solving was used. To prevent 
penetration of liquid in between almond and the seed tegument, samples received a thin layer of paraffin.

\section{Apparent Specific Mass}

The apparent specific mass was determined indirectly by using the equation 04, described by MOHSENIN (1986), which relates the unitary specific mass ( $\left.\rho_{\text {actual }}\right)$ and porosity to determine the apparent specific mass.

$$
\rho_{\text {ap }}=\rho_{\text {actual }}-\rho_{\text {actual }} \varepsilon
$$

wherein,

$$
\begin{aligned}
& \rho_{\mathrm{ap}}=\text { apparent specific mass of the seed mass }\left(\mathrm{kg} / \mathrm{m}^{3}\right) ; \\
& \varepsilon=\text { porosity }(\mathrm{adm}) .
\end{aligned}
$$

\section{Angle of Repose}

To determine the angle of repose of the chestnuts were used only seeds with seed tegument, knowing that the seeds without seed tegument should not be stored in bulk due to the rapid oxidation to which it is subject, this result has little practical importance.

The determination of the angle of repose was performed in a cubic determinant, with dimensions: $0.60 \mathrm{~m} \times 0.60 \mathrm{~m} \times 0.60 \mathrm{~m}$. The equipment has a false bottom, installed to half its height and a gate, allowing the flow of the grain into the false bottom installed to the half of the length. The region above the false bottom and frontal to the equipment was constructed of glass, in order to facilitate the angle viewing.

The determination of the angle of repose was performed based on the principles of trigonometry, which correlates the angles of a triangle by calculating the tangent- arches formed by the cathetus (opposite and adjacent). Equation 05 shows the trigonometric relationships mentioned.

$$
\alpha=\tan ^{-1} \frac{c o}{c a}
$$

where,

$$
\begin{aligned}
& \alpha=\text { angle of } \operatorname{repose}\left({ }^{\circ}\right) ; \\
& \text { co }=\text { opposite cathetus }(\mathrm{cm}), \text { and } \\
& \text { ca }=\text { adjacent cathetus }(\mathrm{cm}) .
\end{aligned}
$$

In Figure $3(\mathrm{a} / \mathrm{b})$ are presented a schematic representation of apparatus used for determining the repose angle.

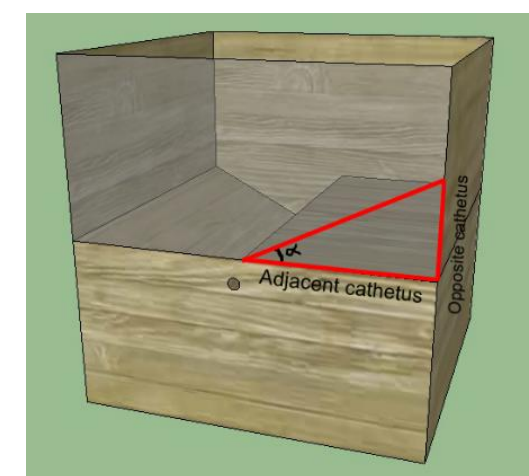

(a)

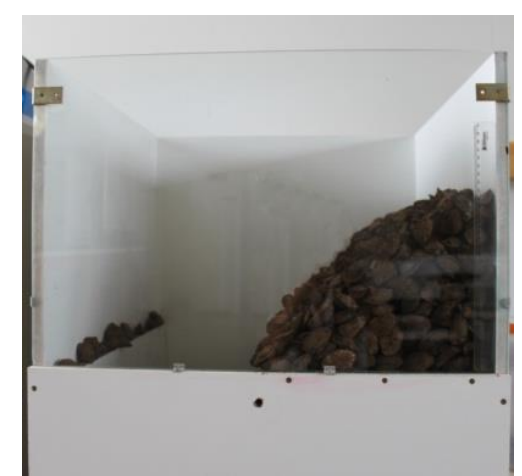

(b)

FIGURE 3. Determinant of the angle of repose(a) Schematic representation and (b) equipment. 


\section{Statistical Analyses}

For this study were applied only concepts of descriptive statistics, since there is no treatment to be evaluated.

\section{RESULTS AND DISCUSSION}

Size

The values found for the size of the almonds with and without seed tegument derived from the municipality of Itaúba-MT in the 2010/2011 harvest can be seen in Table 01 .

TABLE 1. Average values and standard deviation for the size of almonds with and without seed tegument.

\begin{tabular}{lccc}
\hline \multicolumn{1}{c}{ Description } & $\mathrm{X}(\mathrm{mm})$ & $\mathrm{Y}(\mathrm{mm})$ & $\mathrm{Z}(\mathrm{mm})$ \\
\hline Almonds in seed tegument & $39.35 \pm 5.26$ & $24.19 \pm 2.48$ & $17.88 \pm 1.82$ \\
Almonds without seed tegument & $31.05 \pm 3.59$ & $14.38 \pm 1.76$ & $15.91 \pm 1.89$ \\
\hline
\end{tabular}

Based on the values given in the table above, it can be observed that the average for the $\mathrm{Y}$ and $\mathrm{Z}$ axes, when compared between the almonds with and without seed tegument did not follow the same pattern, been the $\mathrm{Y}$ axis dimension higher than the $\mathrm{Z}$ axis for the almond with seed tegument and the reverse was observed for the almond without seed tegument.

This can be explained by the fact that the shape of the almond with seed tegument be different from the almond without seed tegument, in addition there are major differences between the shapes of each individual.

Comparing the present results with those described by SANTOS et.al. (2006), for almonds with seed tegument obtained in Belém, Pará, almonds analyzed had lower average size. In this study, dimensions of $45.86 \mathrm{~mm}$ in the $\mathrm{X}$ axis, $28.12 \mathrm{~mm}$ in the $\mathrm{Y}$ axis and $20.20 \mathrm{~mm}$ in the $\mathrm{Z}$ axis have been found.

\section{Shape} Table 2.

The results obtained for the shape of the almonds with or without seed tegument are shown in

TABLE 1. Average values and standard deviation for the sphericity and roundness of almonds with and without seed tegument.

\begin{tabular}{lcc}
\hline \multicolumn{1}{c}{ Description } & Circularity (\%) & Sphericity (\%) \\
\hline Almonds in seed tegument & $66.40 \pm 5.29$ & $63.00 \pm 4.74$ \\
Almonds without seed tegument & $51.59 \pm 6.08$ & $47.72 \pm 6.18$ \\
\hline
\end{tabular}

Based on data circularity found, it can be stated that the almond with seed tegument has a designed shape closer to a circle than the almond without seed tegument. This can be explained by taking as reference axis for such analyzes, taking more circular portion of the product as base.

It is also worth noting that the difference in form factor between the two products may be related to a protuberance that makes up the fracture line of the seed, which increases, circumstantially, the diameter of the circle inscribed in its projection.

Comparing the data with those cited by MOHSENIN (1986) for other agricultural products, it is noticed that the sphericity obtained for the almond with seed tegument is close to the sphericity of alfalfa with $6.3 \%$ moisture. As for almond without seed tegument, sphericity approximates that found for the one mentioned for rice. 


\section{Mass of 1000 almonds}

An average and standard deviation of 6,127.50 $\pm 228.70 \mathrm{~g}$ was obtained for the almond with seed tegument. As for the almond without seed tegument, the average and standard deviation were $3,180.80 \pm 95.70 \mathrm{~g}$.

As can be seen, the mass of the tegument corresponds to $48.09 \%$ of the weight of the chestnuts and the almond without seed tegument represents $51.01 \%$ of the total weight.

The values found for the Brazil nut are much higher when compared with other nuts, such as pistachios, $194.88 \mathrm{~g}$ (RAZAVI, et.al., 2008), and the pine nut, $930.00 \mathrm{~g}$ (GHARIBZAHEDI, et.al., 2010); but close when compared with the values for the cashew nuts in shell, which is 5,960 $\mathrm{g}$ (BALASUBRAMANIAN, 2001).

\section{Actual specific mass}

In Table 3 we can observe the values of unitary mass, unitary volume and actual specific mass for Brazil nut with seed tegument and without seed tegument.

TABLE 2. Average values and standard deviation of unitary mass, unitary volume and actual specific mass for almonds with and without seed tegument.

\begin{tabular}{lccc}
\hline \multicolumn{1}{c}{ Description } & Mass un. $(\mathrm{g})$ & Volume un. $\left(\mathrm{cm}^{3}\right)$ & Actual specific mass $\left(\mathrm{g} . \mathrm{cm}^{-3}\right)$ \\
\hline Almonds with seed tegument & $6.17 \pm 1.11$ & $6.46 \pm 1.18$ & $0.947 \pm 0.02$ \\
Almonds without seed tegument & $3.30 \pm 0.90$ & $3.29 \pm 0.90$ & $1.003 \pm 0.01$ \\
\hline
\end{tabular}

Based on the above data, it was observed that the specific mass of chestnut with seed tegument is slightly smaller than that of the chestnut without seed tegument because of the existing empty space between almond and the tegument. This space contributes to the increase in unitary volume, without realizing change in its mass.

Considering the values of actual specific mass to other nuts, it is observed that the values are close. RAZAVI, et.al. (2008) found values for the pistachio of 0.996 g.cm ${ }^{-3}$. GHARIBZAHEDI, et.al. (2010) found values of $1.071{\mathrm{~g} . \mathrm{cm}^{-3}}^{-}$for the pine nuts. Finally, for the cashew nuts in shell, BALASUBRAMANIAN (2001) mention values of $1.240 \mathrm{~g} . \mathrm{cm}^{-3} ; \quad$ ARAÚJO \& FERRAZ (2008) found values of $1.020 \mathrm{~g} . \mathrm{cm}^{-3}$.

\section{Porosity}

Almonds with tegument analyzed showed porosity of $46.88 \%$, while the almonds without tegument showed porosity of $37.60 \%$. This can be explained by the fact that almonds with seed tegument present a more irregular shape compared with the almonds without seed tegument, thus hindering their natural arrangement.

Comparing these values with those found in the literature for other products considered chestnuts, it is observed that RAZAVI, et.al. (2008) found values of $40.02 \%$ for the pistachio. GHARIBZAHEDI, et. al. (2010) found values of $44.57 \%$ for the pine nut, both values lower than those found for the Brazil nut. Finally, for the cashew nuts in shell, BALASUBRAMANIAN (2001) quotes values of $52.33 \%$, higher than that found in this study.

\section{Apparent Specific Mass}

Based on the values of actual specific mass and porosity found for the Brazil nut, in Table 4 are given the values for the apparent specific mass of the Brazil nut. 
TABLE 3. Average values and standard deviation for the actual specific mass, porosity and apparent specific mass for almonds with and without seed tegument.

\begin{tabular}{lccc}
\hline \multicolumn{1}{c}{ Description } & Actual specific mass $\left(\mathrm{g} . \mathrm{cm}^{-3}\right)$ & $\begin{array}{c}\text { Porosity } \\
(\text { dec. })\end{array}$ & $\begin{array}{c}\text { Apparent specific } \\
\text { mass }\left(\mathrm{g} . \mathrm{cm}^{-3}\right)\end{array}$ \\
\hline Almonds with seed tegument & $0.947 \pm 0.015$ & $0.468 \pm 0.016$ & 0.504 \\
Almonds without seed tegument & $1.003 \pm 0.011$ & $0.376 \pm 0.008$ & 0.626 \\
\hline
\end{tabular}

Based on the above data, it is observed that the almonds without tegument have higher apparent specific mass than almonds with seed tegument. This is because of lower porosity observed in relation to those with seed tegument, which creates a greater mass of product in the same volume.

Comparing these results with those found for other nuts such as pine nuts, GHARIBZAHEDI, et.al. (2010) found values of apparent specific mass ranging from 593.6 to $612.3 \mathrm{~kg} \mathrm{~m}^{-3}$, close to the values found in this study. RAZAVI, et.al. (2008) studying the apparent specific mass of pistachio found values of $596.36 \mathrm{~kg} \mathrm{~m}^{-3}$, higher than those found for nuts in shell in this study . Values of actual specific mass from 591.9 to $624.2 \mathrm{~kg} \mathrm{~m}^{-3}$ were found by BALASUBRAMANIAN (2001) for cashew nuts in shell, value higher than the value found in this study.

\section{Angle of Repose}

In this study, the medium angle of repose for almonds of Brazil nut with seed tegument was $36.37^{\circ}$.

Figure 4 shows a comparison between the results found in this study to those reported by Silva (2008) for other agricultural products.

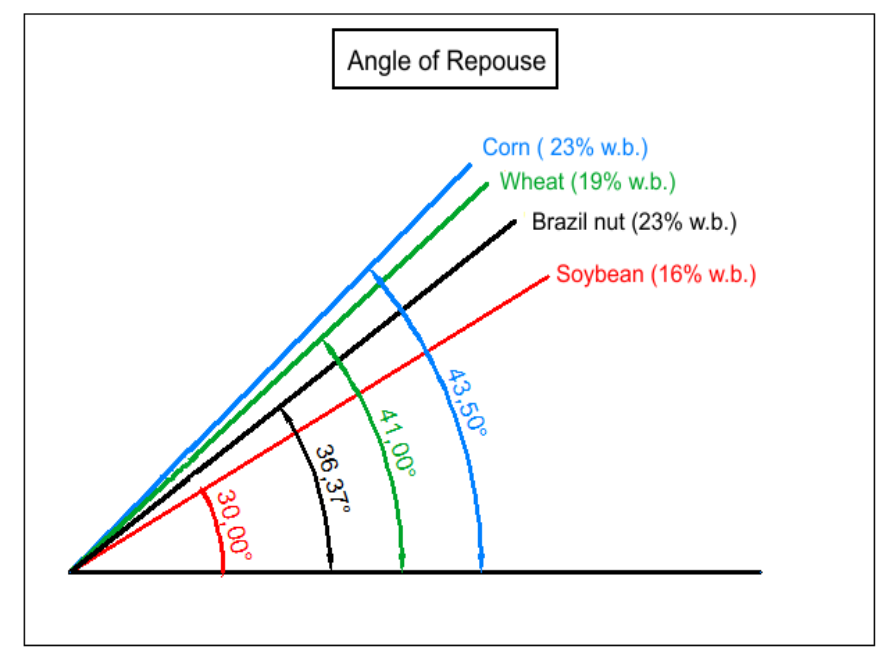

FIGURE 4. Comparison between the values of angle of repose cited by SILVA (2008) and found in this study for the Brazil nut with tegument.

Based on the above figure, it is observed that the values of angle of repose for the Brazil nut are in the observed range for other agricultural products.

\section{CONCLUSIONS}

Based on the results of this study, it can be concluded that:

- the size for the Brazil nut found in this study was lower than those reported for the same product from the state of Pará; 
- the roundness and sphericity of Brazil nut almonds with seed tegument is higher than those for the product without the seed tegument;

- the actual specific mass is lower for nuts with seed tegument when compared with the almond without tegument; for porosity and apparent specific mass has the opposite behavior;

- the angle of repose found for the Brazil nut is close to the values obtained for other agricultural products.

\section{REFERENCES}

ARAÚJO, M.C.; FERRAZ, A.C.O.. Características físicas e mecânicas do endocarpo e da amêndoa da castanha de caju 'CCP 76' antes e após tratamento térmico. RevistaEngenhariaAgrícola, Jaboticabal, v.28, n.3, 2008.

BALASUBRAMANIAN, D. Physical Properties of Raw Cashew Nut.Journal of Agricultural Engineering Research.N $N^{\circ}$ 78, vol 3, 2001.

CORRÊA, P. C.; SILVA, J. S. Estrutura, Composição e Propriedades dos Grãos. In: SILVA, J. S. Secagem e Armazenagem de Produtos Agrícolas. 2a . ed. Viçosa: [s.n.], Cap. 2, 2008.

CARDARELLI, H. R.; OLIVEIRA, A. J. Conservação do leite de castanha-do-Pará. Scientia Agricola, v. 57, n. 4, p. 617-622, out./dez. 2000.

GHARIBZAHEDI, S.M.T.; ETEMAD, V.; MIRARAB-RAZI, J.; FOS'HAT, M. Study on some engineering attributes of pine nut (Pinuspinea) to the design of processing equipment.Research in Agricultural Engineering.Vol. 56, n3, 2010.

LOUREIRO, A. A.; SILVA, M. F..Catálogo de madeiras da Amazônia. Sudan, Belém. 1968

LOUREIRO, A. A.; SILVA, M. F.; ALENCAR, J. C. Essências florestais madeireiras da Amazônia. Manaus: INPA, V.1. 245p. 1979.

MACIEL, R. C. G.; REYDON, B. P.. Produção de castanha-do-Brasil certificada na Resex Chico Mendes: impactos e avaliações. In Congresso Brasileiro da Sociedade de Economia, Administração e Sociologia Rural.2008

MOHSENIN, N.N., Physical Properties of Plant and Animal Materials. New York, Gordon and Breach Science Publications. 1986.

RAZAVI, S.M.A.; MAZAHERINASAB, M.; NICKFAR, F.; SANAEEFARD, H.. Physical properties and image analysis of wild pistachio nut (Raneh). IranianFood Science \& Technology ResearchJournal. vol 2, n 3, 2008.

SANTOS, J.U.M.; BASTOS, M.N.C.; GURGEL, E.S.C.; CARVALHO, A.C.M. Bertholletia excelsa Humboldt \&Bonpland (Lecythidaceae): aspectos morfológicos do fruto, da semente e da plântula. Boletim do Museu Paraense Emílio Goeldi, Ciências Naturais, Belém, PA, v. 1, n. 2, 2006. SANTOS, J. C.; SOUZA, J. M. L.. Castanha-do-Brasil. Embrapa Brasília. 2012.

SILVA, J. S. Secagem e Armazenagem de Produtos Agrícolas. 2a . ed. Viçosa: UFV, 2008.

SOUZA, J. M. L.; CARTAXO, C. B. C.; LEITE, F. M. N.; SOUZA, L.M.. Manual de segurança e qualidade para cultura da castanha-do-Brasil. Campo PAS, Brasília. 